\title{
The Construction of General Chemistry Course in the New Media Era
}

\author{
Linfang Jia ${ }^{1,2, *}$ and Dan Liang ${ }^{1,2}$ \\ ${ }^{1}$ Department of Applied Chemistry, College of Biological Science and Engineering, Beijing \\ University of Agriculture, Beijing, China \\ ${ }^{2}$ Key Laboratory of Urban Agriculture (North China), Ministry of Agriculture, P. R. China \\ Jialinfang73@sina.com
}

Keywords: New media era; General chemistry; Course construction

\begin{abstract}
General chemistry is an important public basic course in agricultural colleges and universities with broad audience and wide application. It is not only the basis for subsequent analytical chemistry, organic chemistry and physical chemistry, but also it is closely related to the specialized courses of biochemistry, environmental chemistry, soil chemistry, food chemistry and so on. General chemistry mainly introduces the basic principles of chemical reaction, the four balances in solution, and the basic knowledge of material structure. It has the characteristics of less time, much content, and some knowledge abstract and difficult to understand. In the classroom, the new media technology and the traditional teaching content are combined to improve the teaching methods, which can make the course content more interesting and more attractive. After class, the establishment of quality course website, discussion groups, and public network channels can help students learn autonomously, timely and effectively solve the problems in the study, strengthen mutual communication between teachers and students, expand their horizons in general chemistry learning, and ultimately achieve the purpose of improving teaching quality.
\end{abstract}

\section{Introduction}

With the development of science and technology and the rapid rise of digital technology in the era of new media, the dissemination of information has broken through the limitation of time and space of traditional media and the single channel of communication. The digital technology in the new media era has infiltrated everybody's life, which in turn has affected the development of students. Students are easily attracted by a variety of media information, and the traditional classroom teaching is less attractive to students, so the teaching effect needs to be improved. At the same time, digital technology in the new media era has the obvious advantages of high speed of communication, immediacy of information and high degree of knowledge fusion. Therefore, how to make full use of the advantages of new media and apply the digital technology as a kind of curriculum resource to general chemistry teaching is a topic of inquiry value.

Characteristics of New Media. The New Media[1-4] concept was first introduced in 1967 by P. Goldmark, director of the CBS Institute of Technology. New media is relative to the traditional media. It refers to the use of modern communications technology, through the network, including the Internet, mobile networks (4G) and other means, send the information(carried by text, images, audio, video, animation, etc. ) to the smart phones, tablets and other terminal equipment, and use certain software to read the way of information transmission [2]. Compared with traditional media, new media has the following characteristics. First, new media is real-time. The speed of dissemination of new media information is very fast, showing a clear real-time characteristics. Internet users can quickly release and receive information in a timely manner through mobile phones, computers or other smart terminals. Second, the new media is interactive. New media has super interactivity compared to traditional media. Traditional media is one-way communication with poor interaction. The media in a strong position, determines what kind of information the audience accepted, and the user is difficult to feedback. But in the new media environment, the transmission of information is two-way or even multi-directional. With the widespread application of new media technologies such as Weibo and WeChat, the public can be 
both the recipient of information and the commenter, creator, publisher and distributor of information which provides a platform for two-way and even multi-directional exchange of information. Third, the new media is ultra-space-time. Using communications satellites and a globally connected network for data transmission, the new media completely broke the space-time constraints of previous information transmission and allowed information to be communicated anywhere in the world. Fourth, the new media is diverse. The majority of users can freely express their views, publish messages, convey information though Weibo, WeChat, blog, QQ, forum, etc. as an important information dissemination tool for new media. A variety of information can be very convenient to be spread, showing a wide range of characteristics.

\section{Changes in the Relationship Between Teachers and Students in the New Media Era}

Teachers and students are the main body of education. The teacher-student relationship is the most basic and important relationship in the process of educational activities. For a long time, due to the restrictions of information dissemination technology, teachers have absolutely occupied the knowledge information. Students acquire professional knowledge mainly from teachers' lectures. Teachers have high prestige and authority among students. The most important relationship between teachers and students is the relationship between imparting and receiving knowledge. At this time, the teacher-student relationship is also called the "pyramid" teacher-student relationship[4].

With the rapid development of information technology, Internet and mobile intelligent terminal technology has been widely used, more and more people have the opportunity to quickly contact the information on the Internet. It provides more possibilities for universal education and lifelong education, and the education industry is constantly adapt and change. With Baidu, Google, 360, Sogou, as the representative of the search engine, iCourse, Netease Open Class, distance education Khan Academy, the product of information age makes teachers and students have the same access to information, and the teacher no longer has the absolute right to occupy the knowledge. The relationship between teachers and students gradually from the original pyramid has evolved into a flat relationship, and teachers and students are more equal. Even, some people are asking, in "the Internet plus" era, will the profession of teachers disappear? Thus, with the development of society, rich learning resources can be obtained anytime and anywhere. Great changes have taken place in the teacher-student relationship. Many teachers are feeling that students are becoming more and more difficult to manage. Therefore, teachers, as organizers of educational activities, also need to adapt to the changes of the times in the concept, teaching means and other aspects to make appropriate adjustments, effectively use the network resources, strengthen curriculum construction. The main issues involved in colleges and universities Educational network resources[5] include the following.

II. I Quality Courses. In 2003, the Ministry of Education of China launched the National quality Curriculum Plan, which requires the establishment of various top-level Courses system at all levels, including schools, provinces and countries. The construction of high-quality courses will improve the overall teaching level, strengthen the construction of teaching staff, promote the reform of teaching content and curriculum system, promote the application of advanced teaching methods and means, and attach importance to the construction of three-dimensional teaching materials with organic combination of various media, promote the combination of teaching and practice, and establish an effective incentive and evaluation mechanism.

II. II Open Global Courses. In 2001, MIT decided to open up their course materials online, free of charge to teachers or learners. All the learning materials follow the Creative Commons protocol, which is called Open Courseware. The Open Courseware Movement also emerges as the times require. Up to now, more than 250 educational institutions in the Open CourseWare sortiums (Open CourseWare sortiums) provide their own learning materials. Great contributions have been made in unlocking of knowledgepromoting equity in education.

II. III Public Video Courses. Due to the influence of OCW, some well-known foreign universities, such as Harvard University, Oxford University and Yale University, offer free video tutorials on some 
excellent teachers. When some domestic subtitle groups, translation agencies, and Netease, Sohu, Sina and other well-known domestic portal launched, Open Video Courses quickly became popular in the country, known as the "Elite Open Class. " In 2011, the Ministry of Education launched the second round of undergraduate teaching project - the construction of national quality open courses, and proposed that during the "12th Five-Year Plan", 1, 000 excellent video open courses should be constructed.

II. IV MOOCs. MOOCs (Massive Open Online Courses) in the original meaning of "large-scale open online course", began in 2008. The sudden outbreak of MOOCs in 2012 set off an upsurge in education and had a significant impact. Within a few short years, a large number of MOOCs operating agencies have emerged in various parts of the world. Many elite schools and famous teachers have joined MOOCs to provide well-produced courses. Such as edX, Coursera, Udacity, OpenLearning and other well-known MOOCs institutions provide a large number of high-quality courses.

II. V Micro-curriculum. Micro-curriculum [6] is a video as the main carrier, around a knowledge point or teaching activities and a teaching activity. Micro-curriculum has the characteristics of short and pithy, each micro-class time is not long, ranging from 5 minutes, as many as 10 minutes, only teach one or two points of knowledge, is a "fragmented" micro-teaching resources. Although the micro-class has less content and small capacity, but it closely combines the well-designed teaching and teaching of the typical case of a close combination of situations, flexible and convenient to use, and can be used in different teaching situations.

\section{New Media in Agricultural Chemistry Colleges and Universities in the Construction of General Chemistry Application .}

General chemistry[7-8] is the first public basic course for undergraduates of agricultural universities. General chemistry is a compulsory course offered by colleges of agriculture, including biology, plant science, animal medicine, animal medicine, foodstuffs, capital resources, and garden plants and forestry, with a large audience and extensive coverage. Conform to the development of the times, continuous education and teaching reform has always been one of the important teaching and research content.

With the continuous improvement of society, the traditional teaching methods have been challenged. The convenience of the network can satisfy the students anytime, anywhere and get the information they want quickly. The teachers' authority is questioned. How to adapt to the trend of the times and make effective use of the new media? The reform of agricultural general chemistry courses is imperative. After years of exploration, our school will continue to deepen the reform[9-11] in the following aspects, with the new media, to achieve the purpose of improving teaching quality.

(1) Combination of in Class and out of Class. Teachers use the classroom time to teach the main points of knowledge, students do exercises under the class. Students share some of the knowledge in the form of internet, students can make full use of extra-curricular time to learn, and help to teach through the curriculum website. Therefore, our school has initially set up an ordinary chemistry course network platform, which can upload courseware-related courseware, after-school exercises, self-test questions bank, postgraduate examination information and other content uploaded for self-study and review after class; meanwhile You can further enrich and improve the content of the website, add some interaction between teachers and students, network answering questions in the form of message, list of reading materials after chemistry, the frontier of chemistry, the application of chemistry in agriculture and life. At the same time the use of WeChat, QQ and other quick and easy features, in the class to establish QQ group, WeChat group, open students online Q \& A pilot, students can ask questions difficult to understand after class and exercises, but also can be comments on teaching methods And suggestions, we all speak freely, so that students in the shortest possible time to solve the problems encountered in learning, greatly improving the teaching efficiency.

(2) Make Good Use of Micro-curriculum to Solve Difficult Problems in the Course. For example, General chemistry experiments may involve some of the more toxic and inconvenient experiments, so teachers can record video in the form of micro-class on the WeChat group and the excellent course Web 
site, and students can choose their own convenient time to learn. You can also put some excellent micro-curriculum resources into the course website, to facilitate students to learn anytime, anywhere.

(3)Constantly Updated Teaching Materials. Knowledge updates faster, modern chemistry can not be reflected in the curriculum, so inevitably there is too old content, novelty is not enough, the appeal is not strong, is not conducive to the excitement of students' interest in learning. Therefore, general chemistry textbooks also need to follow the trend of the times, and combine the essence of traditional knowledge with the principles of modern science, technology and chemistry to continuously strengthen the construction of textbooks. For example, as technology evolves, scanning two-dimensional codes has become an intuitive way to quickly focus on a topic that can be inserted into a textbook using a two-dimensional code, and students can scan the textbook while reading Two-dimensional code to listen to a certain knowledge point or watch a certain experimental process. An experimental video and other content, to facilitate students to quickly grasp the point of knowledge do not understand.

(4) Strengthen Training and Continuously Improve Teachers' Teaching Ability. Teachers can take advantage of on-site and online training opportunities to constantly study, enrich and improve their teaching standards to make their own teaching easier for students to accept. For example, when explaining the content of the electron movement outside the nuclear in the chapter on atomic structure in general chemistry, students generally reflect that this chapter is rather abstract and difficult to understand. We compared the movement of electrons to student dormitories, the track compared to a dormitory for two people, the students compared to electronics, convenient for everyone to understand. For another example, when talking about ideal gas equation of state, we combine the fact that the bike in the summer sun exposure is easy to burst tire; when taking about the contents of the sol coagulation, we combine the knowledge point and the common sense of life that putting some salt in the cooking dumpling water is not easy to break; when talking about the osmotic pressure of the solution, we combine the knowledge of the point with the phenomenon of fertilizer burning seedlings and so on. All of this is to facilitate students to master the knowledge.

\section{Acknowledgements}

This achievement is supported by the general project of education reform of Beijing University of Agricultural (project number: BUA2017JG016).

\section{References}

[1] T. D. Zhang, A. J. Shih and E. Levin: Annals of the CIRP, Vol. 43 (1994) No. 3, p. 305.

[2] N. Kang, T. Wang: Journal of Jiangsu Institute of Education: Social Sciences, (2008) No. 3, p. 6-12. (In Chinese)

[3] J. X. Chen: Industrial \& Science Tribune, Vol. 10(2011) No. 7, 28-29. (In Chinese)

[4] Y. Yuan: Strategic Research on Knowledge Teaching in the New Media Era(M. D. , Southwest University, China 2016). (In Chinese)

[5] J. Yan: Popular Sciences \& Technology, (2016) No. 5, p. 120-122. (In Chinese)

[6] Information on http://course. bua. edu. cn

[7] R. Li: Science and Education Wenhui, (2016) No. 12, p. 1-3. (In Chinese)

[8] S. D. Zhao:General Chemistry(China Agricultural University Press, China 2007)

[9] C. N. Wang and J. Shi: General Chemistry(China Agricultural Press, China 2014)

[10] Y. M. Zhang:Logistics Teaching, (2016) No. 36, p. 195-196. (In Chinese)

[11]D. D. Kong , C. P. Huang: Experimental Technology and Management, (2015) No. 32, p. 22-25. (In Chinese)

[12] M. M. Xu, J. L. Yao:Teaching Reform, (2016) No. 5, p. 38-39. (In Chinese) 